Journal of Applied Veterinary Sciences, 5 (3): 71 - 77 (2020).

ISSN: Online: 2090-3308, Print: 1687-4072

Journal homepage : https://javs.journals.ekb.eg

\title{
Possibility of Using Urine Samples for Detection of Bovine Viral Diarrhea Virus in Egyptian Cattle

\author{
Marwa F. Mahmoud ${ }^{1}$, Hassan H.M. ${ }^{2}$ and Jehan A. Gafer ${ }^{3}$ \\ ${ }^{1}$ Virology Unit in Reproductive Disease Department, Animal Reproduction Research Institute (ARRI), \\ Agriculture Research Center (ARC), Giza, Egypt. \\ ${ }^{2}$ Immunology unit, Animal Reproduction Research Institute, Agriculture Research Center, Giza, Egypt. \\ *Corresponding Author, Marwa F. Mahmoud, E-mail: marwa.abdelmonem@arc.sci.eg
} \\ ${ }^{3}$ Biotechnology unit, Animal Reproduction Research Institute, Agriculture Research Center, Giza, Egypt. \\ ORCID: https://orcid.org/0000-0002-7868-0005
}

\begin{abstract}
This study aims to employ urine as an easily accessible sample for the detection of bovine viral diarrhea virus (BVDV). Thus, a periodic scan can be applied easily to reach an efficient control of the disease. A total of 86 different samples collected from 30 animals (dams $n=23$ and calves $n=7$ ) were raised in a farm with 1,200 cattle in the El-Fayoum district in Egypt with a case history of abortions were used for this study. All samples were subjected to virological investigation using indirect fluorescent antibody technique (IFAT) and virus neutralization tests (VNT) to detect BVDV. Isolation of the virus was achieved using MDBK cells. The isolates were confirmed using reverse transcriptase polymerase chain reaction. The BVDV was detected in nasal swabs in $63.33 \%$ and $70 \%$ using IFAT and VNT. In urine samples, the virus was detected with $46.66 \%$ and $43.33 \%$ by IFAT and VNT, respectively. BVDV was detected in most of the tissues of aborted fetuses in both techniques. Vaginal swabs revealed positive results in $53.85 \%$ and $61.54 \%$ by IFAT and VNT, respectively. Isolates were confirmed by RT-PCR by successful amplification of $288 \mathrm{bp}$. Statistical analysis revealed good correlation of urine samples and other samples. In conclusion, the BVDV virus can be isolated from urine samples. To the best of our knowledge, this is the first work that provides an overview of urine usability as an alternative sample for BVD virus diagnostics in Egypt. The recommendation for further studies should elucidate on a large scale population.
\end{abstract}

Keywords: BVDV, cattle, detection, Egypt, urine samples.

\section{Original Article:}

DOI: HTTPS://DX.DOI.ORG/10.21608/JAVS.2020. $\underline{100145}$

Received : 08 April, 2020.

Accepted : 28 June, 2020.

Published in July, 2020.

This is an open access article under the term of the Creative Commons Attribution 4.0 (CC-BY) International License . To view a copy of this license, visit http://creativecommons.org/licenses/by/4.0/

\section{INTRODUCTION}

Bovine viral diarrhea virus (BVDV) is a major cattle pathogen and has a global distribution, giving rise to various clinical manifestations, including reproductive failure, and respiratory and gastrointestinal tract diseases (Paul et al., 2008; Khodakaram-Tafti and Farjanikish 2017).

Bovine viral diarrhea virus (BVDV) is an individual of the genus Pestivirus, belonging to the family Flaviviridae. It is a small, spherical, positivesense single-stranded, enveloped RNA virus of 40 to $60 \mathrm{~nm}$ in diameter (Scott et al., 2013). It infects cattle of all ages and is distributed worldwide, although some countries have recently eradicated it. BVDV may be subclinical or can become a severe fatal disease. Calves infected during the first trimester of gestation are almost persistently infected (PI) and become reservoirs and excrete large amounts of the virus in urine, feces, discharges, milk, and semen without displaying any apparent signs. Thus, the trade of such cattle is prohibited (OIE, 2018). A high level of positive antibodies in cattle indicates the presence of PI animals on the farm. In other words, the antibodies found in serum and milk point to the presence of PI cattle (Ståhl and Alenius 2012). The shared factors of all fruitful control programs are orderly control, the expulsion of PI cattle, development controls for contaminated crowds, strict biosecurity, and observation (Volker and Paul 2018); however, in our undeveloped country, we depend on vaccine programs. Egypt uses an inactivated BVDV vaccine, but there are no parameters 
to detect or eliminate PI calves from farms (Soltan $\boldsymbol{e t}$ al., 2015). Virus isolation is a gold standard due to its high specificity; moreover, it leaves the virus available for further study. Positive animals should have their samples retested three to four weeks later to distinguish between PI and TI (Larson et al., 2004).

Cytopathogenic BVD, appear to be the cause of acute infections and can be transmitted in a wide range of body fluid including urine (Meyling $\boldsymbol{e t}$ al., 1990; Sasha et al., 2014). Since the involvement of easily available samples for the diagnostic of viral diseases may be significant. Moreover, during an outbreak, an evaluation of appropriate sampling for laboratory analysis is very vital. This will help to achieve optimal diagnostic results for reliable identification. Therefore, the study aims to detect and isolate BVDV from urine to open a new channel for routine usage of these samples because of its ease, safe and economical so that it can help in wide scanning of the virus for efficient control of the disease.

\section{MATERIALS AND METHODS}

\section{Animals}

Animal maintenance and care conformed to recommend International Guiding Principles for Biochemical Research Involving Animals (National Research Council, US, Institute for Laboratory Animal Research, 2004).

A total of 30 animals (dam $n=23$ and calves $\mathrm{n}=7$ ) were raised in a farm with 1,200 cattle in the ElFayoum district in Egypt with 12 abortion cases within six months and were studied during 2019. The farm has a case history of vaccination against BVDV.

\section{Samples}

Thirty (30) Nasal swabs, 30 urine samples (taken by catheter in addition to 7 samples collected without catheter were excluded from the total number due to bacterial contamination), 13 vaginal swabs and 13 tissues of aborted fetuses were taken from dams and their aborted fetuses as well as newborn calves (1-3 months old) the detailed data are depicted in table (1).

\section{Virus isolation (VI)}

It was performed on the nasal swabs, urine samples, vaginal swabs, and tissues of the aborted fetuses collected from the dames and calves. The samples were brought in PBS to room temperature, vortexes, and centrifuged at 2,000 rpm for $5 \mathrm{~min}$. The supernatants were diluted 1:5 with minimal essential medium, and $200 \mu \mathrm{L}$ of each sample was inoculated in duplicate in 96-well plates cultured with Madin-Darby Bovine Kidney cells (MBDK). The BVDV Nadel strain was used as the positive control and a cell culture medium blank served as the negative control. The plates were incubated for five days at $37^{\circ} \mathrm{C}$ in a $\mathrm{CO} 2$ incubator. Four blind passages were done on MDBK cells, followed by three successive passages. The last passage plates were washed with $1 \times \mathrm{PBS}(\mathrm{pH}$ 7.4) and fixed with $80 \%$ aqueous acetone. They were labeled with reference BVDV antisera for $1 \mathrm{hr}$ at $37^{\circ} \mathrm{C}$ and were diagnosed with IFAT.

Table 1: Type and number of samples

\begin{tabular}{|ccccc|}
\hline Animal & \multicolumn{3}{c|}{ Dams $\mathrm{n}=23$} & \\
\cline { 2 - 5 } $\begin{array}{c}\text { Type of } \\
\text { samples }\end{array}$ & $\begin{array}{c}\text { Aborted } \\
(\mathrm{n}=13)\end{array}$ & $\begin{array}{c}\text { Non } \\
\text { aborted } \\
(\mathrm{n}=10)\end{array}$ & $\begin{array}{c}\text { Calves } \\
(\mathrm{n}=7)\end{array}$ & Total \\
\hline Nasal swabs & 13 & 10 & 7 & 30 \\
\hline $\begin{array}{c}\text { Tissues of } \\
\text { aborted fetuses }\end{array}$ & 13 & - & - & 13 \\
\hline Vaginal swabs & 13 & - & - & 13 \\
\hline Urine & 13 & 10 & 7 & 30 \\
\hline Total & 52 & 20 & 14 & 86 \\
\hline
\end{tabular}

\section{Serological tests}

4.1. IFAT: The plates that had previously been prepared for VI were washed with $1 \times$ PBS, labeled with anti-bovine conjugated fluorescein isothiocyanate (FITC), and incubated for $1 \mathrm{hr}$ at $37^{\circ} \mathrm{C}$. A positive IFAT result was based on the direct visualization of cytoplasmic apple green fluorescence in the cells.

4.2. VNT: Two-fold serial dilutions of the sera (1:21:256) were tested using $100 \mathrm{TCID}_{50}$ of BVDV (Nadel strain) in the presence of reference positive antisera, as previously described by Martinelle et al., (2011).

\section{Molecular assay}

\section{Reverse transcriptase polymerase chain reaction (RT PCR)}

\subsection{Nucleic acid Extraction}

RNA Extraction: RNA was extracted from nasal, serum and tissue samples as well as reference strain (BVDV-NADL strain with a titer $10^{6}$ TCID $_{50}$ ) using Biozol (Total RNA Extraction Reagent) Bioflux Cat\# BSC51M1 according to manufacture instructions using 200mg of sample and $1 \mathrm{ml}$ of Biozol.

\section{2. cDNA synthesis}

Five (5ul) of RNA template was reverse transcribed to cDNA at $25^{\circ} \mathrm{C}$ for 5 min followed by incubation at $42^{\circ} \mathrm{C}$ for $60 \mathrm{~min}$. Finally, the reverse transcription reaction was stopped by heating the samples to $70^{\circ} \mathrm{C}$ for $5 \mathrm{~min}$. Using Revert AidTM H Minus First-strand cDNA synthesis Kit (Fermentas Life sciences Lot: 00059751) according to manufacture instructions.

\subsection{PCR amplification}

Amplifications were performed in $25 \mu 1$ reactions containing $5 \mathrm{ul}$ of genomic templates, $1 \mathrm{X}$ of master mix (Dream Taq Green PCR Master Mix, 
Fermentas Life Science) and 25pmol of primer pair of a conserved region of BVDV 5'UTR, forward (5'ATG CCC WTA GTA GGA CTA GCA -3') and reverse (5' - TCA ACT CCA TGT GCC ATG TAC -3') as described by Tramuta et al. (2011). Cycle parameters for PCR were as follows: initial denaturation at $95^{\circ} \mathrm{C}$ for 15 min followed by 35 cycles of ( denaturation at $94^{\circ} \mathrm{C}$ for $1 \mathrm{~min}$, annealing at $55^{\circ} \mathrm{C}$ for $1 \mathrm{~min}$, and extension at $72^{\circ} \mathrm{C}$ for $1 \mathrm{~min}$ ), and finally terminated by a single cycle of a final expansion at $72^{\circ} \mathrm{C}$ for $10 \mathrm{~min}$. The RT-PCR-amplified products were analyzed by electrophoresis in a $1.5 \%$ agarose gel, stained with ethidium bromide and visualized using a UV transilluminator.

\section{Statistical analysis}

Data analysis has been done using graph prism software 2020. The data has been run as nonparametric, so Sperman correction between the types of sampling each assay has been done.

\section{Virus isolation}

\section{RESULTS}

The last three successive passages showed cytoplasmic vacuolation, cell rounding, and detachment from the cell sheet, and cell death, as observed in Fig.(1).
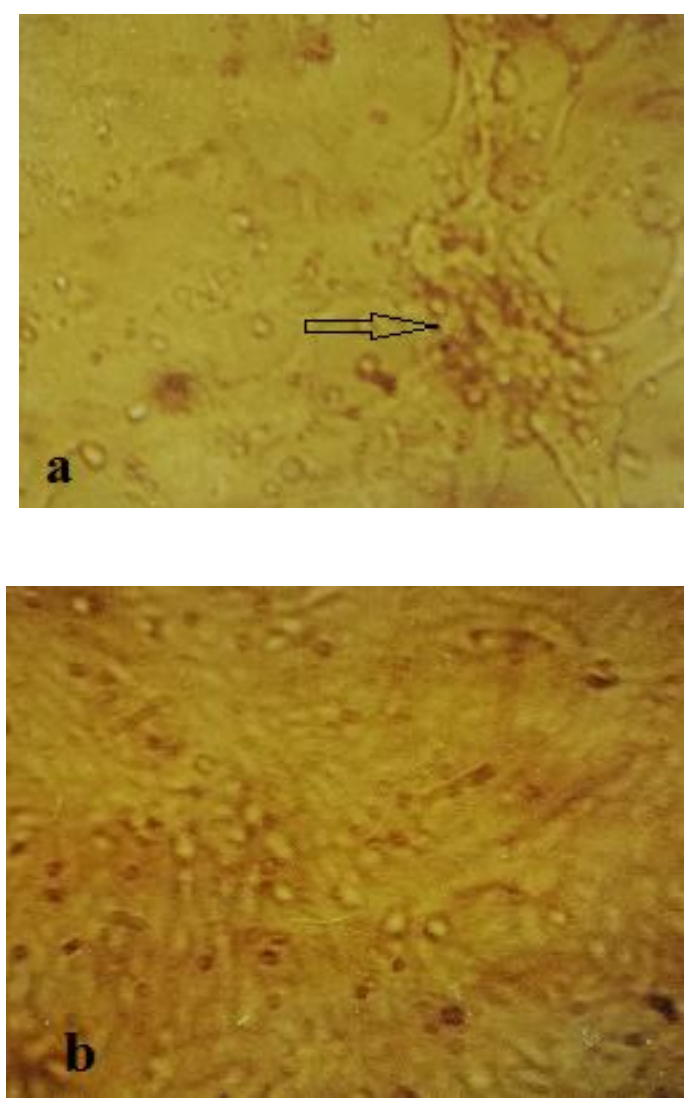

Fig.1(a and b): Representative image of the cytopathic effects of BVDV on MDBK cells showing cytoplasmic vacuolation and cell rounding.

\section{IFAT}

The MDBK cells labeled with FITC were examined by fluorescent microscopy. The infected cells displayed a diffuse intracytoplasmic yellowishgreen color in the positive samples, as shown in Fig (2).
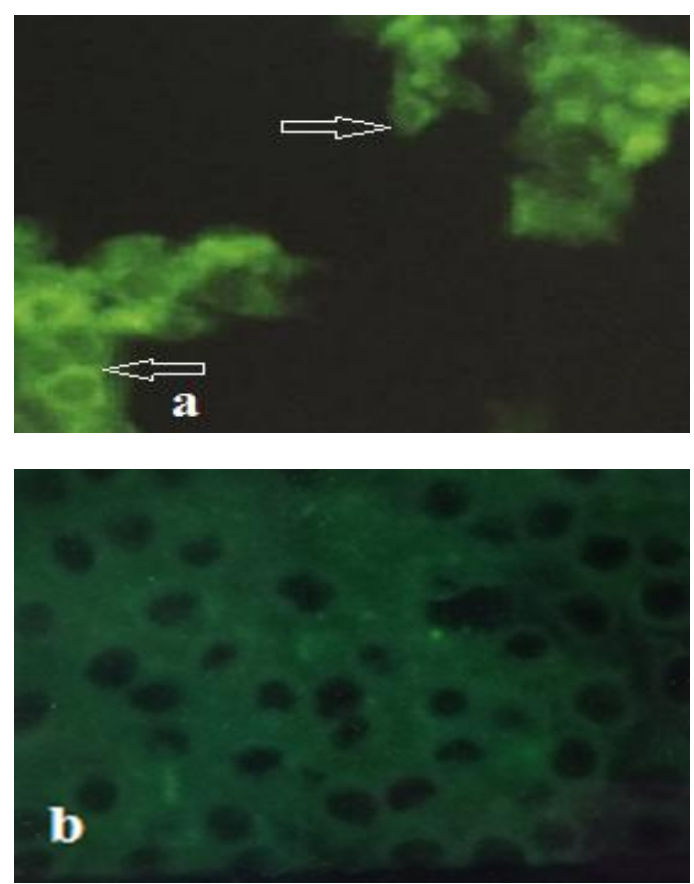

Fig. 2 ( $a$ and $b$ ): Representative image of BVDVpositive cells in the collected samples.

\section{VNT}

In the dams, 21 of the 30 nasal swabs, 13 of the 30 urine samples (obtained by catheters), and 8 of the 13 vaginal swabs were BVDV positive. Most of the tissues derived from the aborted fetuses were BVDV positive, as mentioned in Table (2).

Table 2: Results of detection of BVDV in different samples using IFAT and VNT

\begin{tabular}{|cccccc|}
\hline \multirow{2}{*}{$\begin{array}{c}\text { Type of } \\
\text { Samples }\end{array}$} & \multirow{2}{*}{$\begin{array}{c}\text { No. of } \\
\text { samples }\end{array}$} & \multicolumn{2}{c}{ IFAT } & \multicolumn{2}{c|}{ VNT } \\
\cline { 3 - 6 } & $+\mathrm{VE}$ & $-\mathrm{VE}$ & $+\mathrm{VE}$ & $-\mathrm{VE}$ \\
\hline $\begin{array}{c}\text { Nasal } \\
\text { swabs }\end{array}$ & 30 & $\begin{array}{c}19 / 30 \\
(63.3 \%)\end{array}$ & $\begin{array}{c}11 / 30 \\
(36.6 \%)\end{array}$ & $\begin{array}{c}21 / 30 \\
(70.0 \%)\end{array}$ & $\begin{array}{c}9 / 30 \\
(30.0 \%)\end{array}$ \\
\hline Urine & 30 & $\begin{array}{c}14 / 30 \\
(46.6 \%)\end{array}$ & $\begin{array}{c}16 / 30 \\
(53.3 \%)\end{array}$ & $\begin{array}{c}13 / 30 \\
(43.3 \%)\end{array}$ & $\begin{array}{c}17 / 30 \\
(56.6 \%)\end{array}$ \\
\hline $\begin{array}{c}\text { Tissue of } \\
\text { aborted } \\
\text { fetuses }\end{array}$ & 13 & $\begin{array}{c}11 / 13 \\
(84.6 \%)\end{array}$ & $\begin{array}{c}2 / 13 \\
(15.3 \%)\end{array}$ & $\begin{array}{c}11 / 13 \\
(84.6 \%)\end{array}$ & $\begin{array}{c}2 / 13 \\
(15.3 \%)\end{array}$ \\
\hline $\begin{array}{c}\text { Vaginal } \\
\text { swabs }\end{array}$ & 13 & $\begin{array}{c}7 / 13 \\
(53.8 \%)\end{array}$ & $\begin{array}{c}6 / 13 \\
(46.1 \%)\end{array}$ & $\begin{array}{c}8 / 13 \\
(61.5 \%)\end{array}$ & $\begin{array}{c}5 / 13 \\
(38.4 \%)\end{array}$ \\
\hline
\end{tabular}

Eight of the 30 positive nasal swabs and five tissues of aborted fetuses showed high BVDV titers (128). While most of the urine samples were negative and the BVDV positive urine samples have low titer. The titers of the samples are detailed inTable (3). 
Table 3: BVDV titers in the samples from infected dams and calves were estimated by the virus neutralization test (VNT)

\begin{tabular}{|c|c|c|c|c|c|}
\hline \multirow{2}{*}{ Sample } & \multicolumn{5}{|c|}{ BVDV titers } \\
\cline { 2 - 6 } & $(-\mathrm{ve})$ & $4-8$ & $16-32$ & 64 & 128 \\
\hline Nasal swabs & 9 & 3 & 3 & 7 & 8 \\
\hline Urine & 17 & 5 & 4 & 3 & 1 \\
\hline $\begin{array}{c}\text { Tissues of } \\
\text { aborted } \\
\text { fetuses }\end{array}$ & 2 & 1 & 1 & 4 & 5 \\
\hline $\begin{array}{c}\text { Vaginal } \\
\text { swabs }\end{array}$ & 5 & 2 & 3 & 2 & 1 \\
\hline
\end{tabular}

\section{Reverse transcriptase polymerase chain reaction} (RT PCR):

BVDV positive samples were confirmed by RT-PCR and specific amplification of 288bp was achieved as shown in Fig. (3).

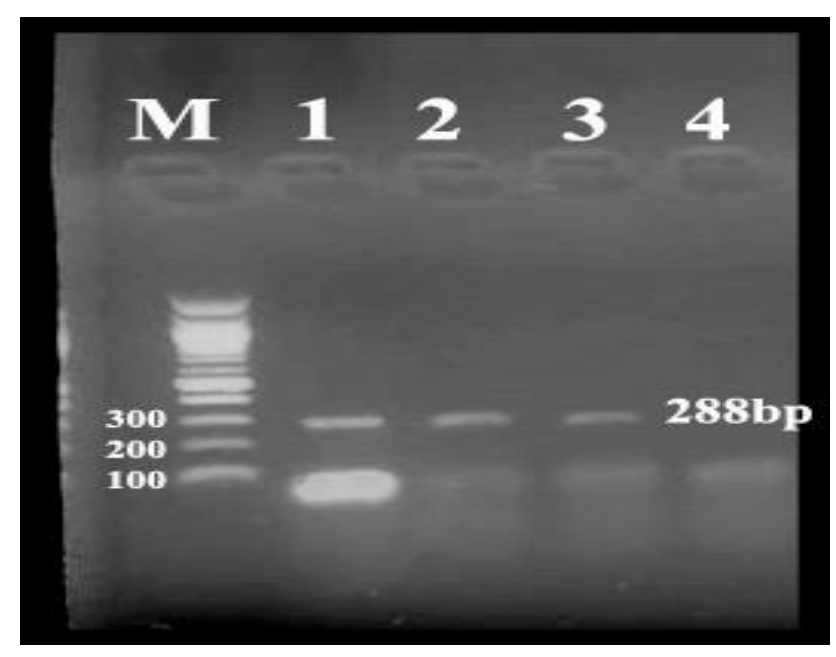

Fig. 3: Shows ethidium bromide stained 1.5\% agarose gel electrophoresis of RT PCR products. Lane M: 100bp DNA ladder, Lane 1: positive controls of BVDV-NADL a reference strain with a titer $10^{6}$ $\left.\mathrm{TCID}_{50} 288 \mathrm{bp}\right)$, Lanes $(2,3)$ : Positive samples, Lane 4: Negative control

\section{Results of statistical analysis}

For the VNT, Fig. 4a is a scatter data plot with 30 samples collected from aborted, non-aborted calves. There was a correlation between Nasal samples with an $\mathrm{R}$-value of $0.53,0.74$ and 0.29 with tissues, vaginal and urine samples (Fig.4b). There was a significant p-value difference between the nasal with tissue and vaginal samples but not a urine sample. The correlation between the tissue samples to the nasal, vaginal and urine was $0.53,0.31$ and 0.63 , respectively.

It showed a high relationship between tissue samples and urine. And there was p-value significant difference between tissue samples and both urine and nasal but not vaginal. Vaginal samples showed the highest correlation of 0.86 with the urine samples with a significant $p$-value of 0.004 . Then 0.74 for nasal with significant $\mathrm{p}$-value and 0.31 for tissues with no significant $\mathrm{p}$-value were noticed. The urine samples showed $0.3,0.64$, and 0.86 with nasal, tissue and vaginal, respectively and $\mathrm{p}$ values significant with tissue and vaginal but not nasal.
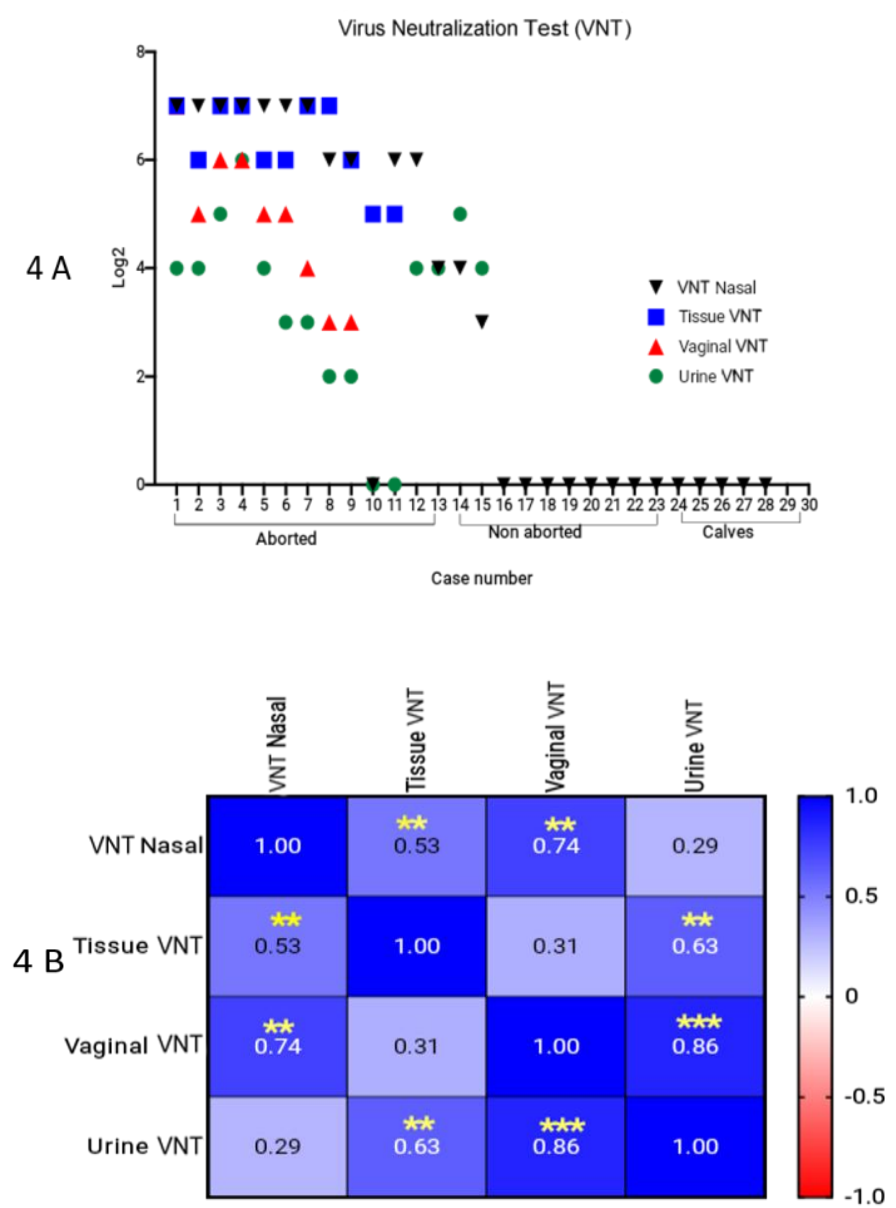

Fig.4: VNT test correlation of different samples. Fig. 4.A: is a scatter correlation scatter data plot with 30 samples collected from aborted, non-aborted and calves. The data has plotted as $\log 2$ VNT titer for each individual sample. Fig.4.B: Spearman (non-parametric test) correlation using Graph prism 2020, has been done to compute $\mathrm{R}$ value between every pairs were performed separately for each assay, and two tail $p$ value significant differences are shown as follows: $* P<0.1$, $* * P<0.01, * * * P<0.001$, and $* * * * P<0.0001$. The correlation coefficient, denoted by $\mathrm{r}$, is a measure of the strength of the straight-line or linear relationship between each two samplebased tests. $\mathrm{R}$ value above 0.4 to 1 consider relatively strong; 0.2 to 0.4 are moderate, and below 0.2 are considered weak correlation. The colored scale for $\mathrm{R}$ value toward blue is highly correlated.

For the IFAT,Fig. 5a is a scatter data plot with 30 samples collected from aborted, non-aborted dams and calves. Fig. $5 \mathrm{~b}$ showed a correlation between Nasal samples with an R-value of $0.52,0.68$ and 0.83 with tissues and vaginal and urine samples. There was a significant $p$ values differences between the nasal with urine and vaginal samples but not tissue sample. The 
correlation between the tissue samples to the nasal, vaginal and urine was $0.52,0.36$ and -0.13 , respectively. It showed a high correlation between tissue samples and nasal samples with no significant pvalue. Vaginal samples showed the highest correlation of 0.68 of nasal samples with a significant $p$-value of 0.01 . Then 0.53 with urine with a significant $\mathrm{p}$-value of 0.1 and 0.36 for tissues with no significant $\mathrm{p}$-value. The urine samples also showed the highest correlation of 0.83 with nasal samples with a very significant $p$ value of 0.0001 . then 0.53 in vaginal samples with a significant p-value of 0.1 and -0.13 , in tissue samples with no significant $\mathrm{p}$-value.

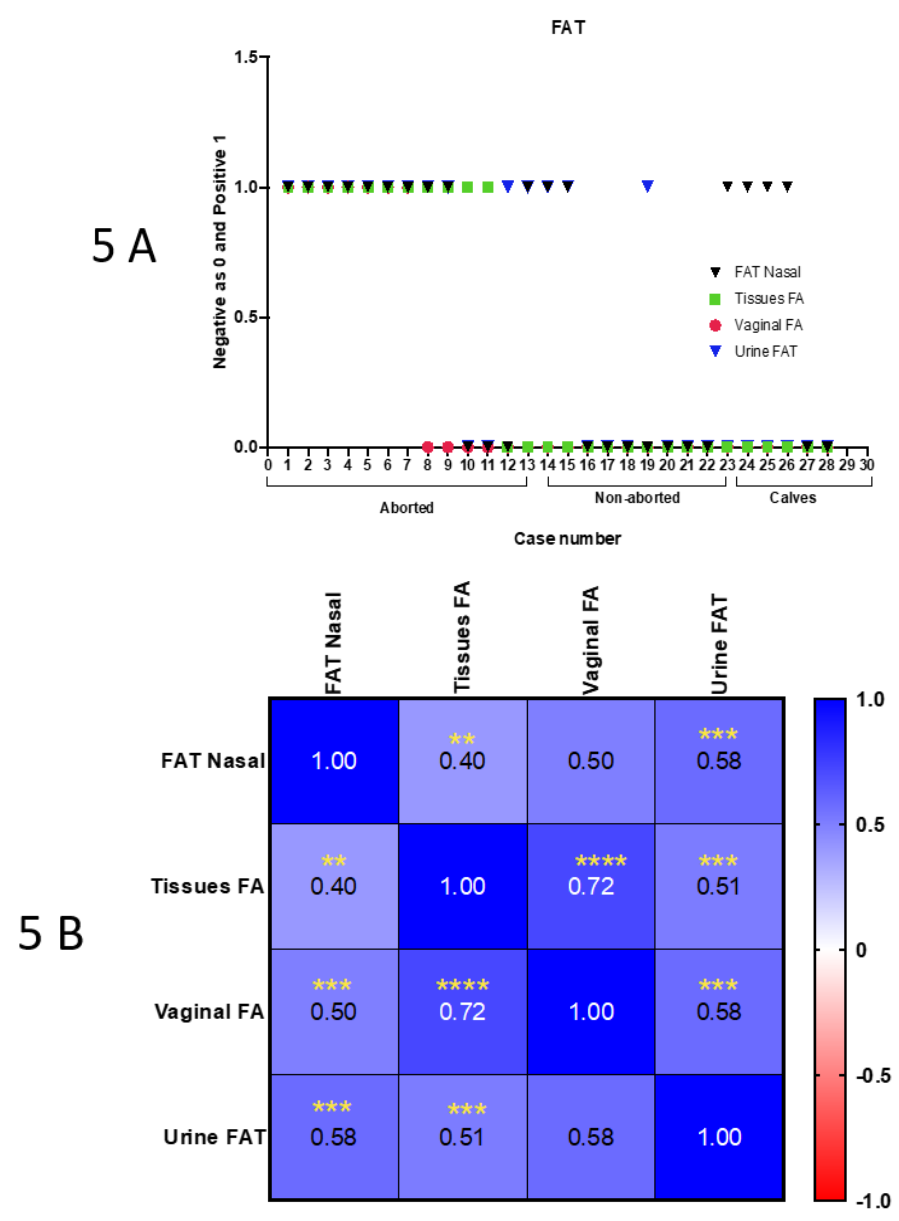

Fig. 5: FAT test correlation of different samples. 5.A: is a scatter correlation scatter data plot with 30 samples collected from aborted, non-aborted and calves. The data has plotted as positive as 1 and negative as 0 for each individual sample. 5.B: Spearman (non-parametric test) correlation using Graph prism 2020, has been done to compute R value between every pairs were performed separately for each assay, and two tail $\boldsymbol{p}$ value significant differences are shown as follows: $* P<0.1, \quad * * P<0.01, \quad * * * P<0.001$, and $* * * * P<0.0001$. The correlation coefficient, denoted by $\mathrm{r}$, is a measure of the strength of the straight-line or linear relationship between each two sample-based tests. R value above 0.4 to 1 consider relatively strong; 0.2 to 0.4 are moderate, and below 0.2 are considered weak correlation. The colored scale for $\mathrm{R}$ value toward blue is highly correlated.

\section{DISCUSSION}

Successful animal production systems are dependent on effective reproduction. Although high fertilization rates of up to $90 \%$ have been reported, up to $65 \%$ of embryos are assessed to be lost before term, leading to significant economic losses to the animal industry (Okumu et al., 2019).

In this study, cows suffering from miscarriages on a farm with 1,200 cattle in the El-Fayoum district in Egypt were diagnosed to confirm their infection with BVDV and differentiate between infected and uninfected calves. The results revealed the circulation of bovine viral diarrhea virus on the farm. This observation may be due to new cows entering the farm without adequate quarantine and possibly the presence of persistently infected cattle (Ståhl and Alenius 2012).

As shown in table (2) BVDV was detected with high percentages of $70 \%$ of nasal swabs, $84.62 \%$ in the tissue of aborted fetai and the high titers identified in most samples, indicate that the virus was able to replicate and spread to susceptible cattle (BAULE et al., 2001). Many genome regions have been used to recognize pestiviruses, by using RT-PCR in particular, the 5'UTR and Npro regions show a high degree of conservation among pestiviruses, making them appropriate for detection of a broad range of viruses and strain discrimination studies (Hofmann $\boldsymbol{e t}$ al., 1994; Becher et al., 2003; Sharifzadeh et al., 2011).

In the current study, a fragment of $288 \mathrm{bp}$ of 5'UTR a highly conserved fragment of the BVDV genome, could be amplified so that the results from this assay become more sensitive. The same primer was previously used successfully (Trumuta et al., 2011; Wang et al., 2014; Gafer et al.,2015). Some reports have shown that human viruses like ZIKV and CHIKV can be detected in unusual body fluids like saliva and urine (Barrzon et al., 2016; Abdalla et al., 2018; Vldinete et al., 2020). Moreover, urine BVD viral shedding was previously documented in alpacas (Stacey et al.,2011),

Because of the bacterial contamination of some urine samples, this study's assessment of the urine samples for the detection of BVDV is insufficient. However, the urine samples available had a range of titers between 32 and 64. When the BVDV titer is more than 4, it is considered positive (Robert et al., 1995). In our study, BVDV was identified in the liver, spleen and lungs of aborted fetuses with a high titer of 128 in five fetuses. The same result was reported previously (Maximiliano et al., 2018). In this study, the negative results obtained from some urine samples may be due to improper collection, storage, or processing or probably represent a true negative period of shedding. 
Statistical analysis presented in this work revealed a good correlation of urine samples and other samples commonly used in the detection of BVDV indicating the possibility of this sample to be used in the detection of BVDV This result has potential importance as urine sample collection is non-invasive, cheap, and easy to perform particularly relevant under conditions in which blood samples collection may be problematic (Chantal et al., 2017). Due to the rarity of the literature on the use of urine samples as an alternative or even complimentary samples in the detection of BVDV, it is difficult to compare our results with others.

\section{CONCLUSIONS}

Bovine Viral Diarrhea virus can be isolated from urine samples. There is a respectable correlation between urine samples and other samples commonly used in detecting BVDV and providing an overview of the possibility of using urine samples in the identification of BVDV in Egypt. Further studies on the probability of usages of urine samples for detection of BVDV should elucidate on a large scale population for providing a favorable alternative sample for the routine diagnostic and promising diagnostic approach for large surveillance studies.

\section{Conflict of Interest}

There are no actual or potential conflicts of interest including any financial, personal or other relationships with other people or organizations within three years of beginning the submitted work that could inappropriately influence, or be perceived to influence, our work.

\section{REFERENCES}

ABDALLA LF, SANTOS JHA, BARRETO RTJ, SOUZA EME, D'ASSUNÇÃO FF, BORGES MA, ET AL. 2018. Atrial fibrillation in a patient with Zika virus infection. Virol J.; 15(1): 23. doi: 10.1186/s12985-018-0938-2.

BARZON L, PACENTI M, BERTO A, SINIGAGLIA A, FRANCHIN E, LAVEZZO E, ET AL. 2016. Isolation of infectious Zika virus from saliva and prolonged viral RNA shedding in a traveler returning from the Dominican Republic to Italy, January 2016. Euro Surveill.; 21(10): 30159.

BaUle, C., KUlCSA G., Bela K., AlberT, M., MITTELHOLZER, C., SOO' S, T., KUCSERA, L.and BELA'K. 2001. Pathogenesis of Primary Respiratory Disease Induced by Isolates from a New Genetic Cluster of Bovine Viral Diarrhea Virus Type I. J. Clin. Microbiol.39:146-153.

BECHER, P., R. AVALOS RAMIREZ, M. ORLICH, S. CEDILLO ROSALES, M. KONIG, M. SCHWEIZER, H. STALDER, H. SCHIRRMEIER AND H.J. THIEL, 2003. Genetic and antigenic characterization of novel pestivirus genotypes: implications for classification. Virology. 311: 96-104.

CHANTAL, B. E. M., REUSKEN, MARJOLEIN KNOESTER,B CORINE GEURTSVAN KESSEL,A MARION KOOPMANS,A,C DAAN G. KNAPEN,D WOUTER F. W. BIERMAN,D SUZAN PASA, 2017. Urine as Sample Type for Molecular Diagnosis of Natural Yellow Fever Virus Infections. Journal of Clinical Microbiology 55: (11) 3294-3296.

GAFER J.A.; THANAA K. H.; HALA A. S. AND MADBOLY. M. 2015. Genetic detection and pathological finding of Band bhv-1 in camel calves. Assiut Vet. Med. J. 61 (146) 34-45.

HOFMANN, M.A., K. BRECHTBUHLVDV AND N. STAUBER, 1994. Rapid characterization of new pestivirus strains by direct sequencing of PCRamplified cDNA from the 5' noncoding region. Archives of Virology, 139: 217-229.

KHODAKARAM-TAFTI, A. AND FARJANIKISH GH. 2017. Persistent bovine viral diarrhea virus (BVDV) infection in cattle herds. Iran J Vet Res.18(3): 154-163.

LARSON RL, GROTELOESCHER DM, BROCK KV, HUNSAKER BD, SMITH RA, MACGREGOR DS AND DARAGATZ DA. 2004. Bovine Viral Diarrhea (BVD): review for beef cattle veterinarians. Bov. Pract.; 38:93-102.

MAHMOODI P, SHAPOURI MR, GHORBANPOUR M, HAJIKOLAEI MR, LOTFI M, BOROUJENI MP AND DAGHARI M. 2015. Simple Indirect EnzymeLinked Immunosorbent Assay to Detect Antibodies Against Bovine Viral Diarrhea Virus, Based on Prokaryotically Expressed Recombinant MBP-NS3 Protein. Jundishapur J Microbiol. 8(3): e14311.

MARTINELLE L, DAL POZZO F, SARRADIN P, DE LEEUW I, DE CLERCQ K, THYS C, ZIANT D, THIRY E AND SAEGERMAN C. 2011. Two alternative inocula to reproduce bluetongue virus serotype 8 diseases in calves. Vaccine; 29(19):3600-9.

MEYLING, A.; HOUE, H.; AND JENSEN, A.M. 1990. Epidemiology of bovine virus diarrhea virus. Revue Scientifique et Technique (International Office of Epizootic) 9, 75-93.

NATIONAL RESEARCH COUNCIL (US) INSTITUTE FOR LABORATORY ANIMAL RESEARCH. 2004. The Development of sciencebased Guidelines for Laboratory Animal Care: Proceedings of the November 2003 International workshop. Washington (DC): National Academies Press (US); D:, International Guiding Principles for Biomedical Research Involving Animals (1985) Available https://www.ncbi.nlm.nih.gov/books/NBK25438

OIE. 2018. Bovine Viral Diarrhoea. Chapter 3.4.7.

https://www.oie.int/fileadmin/Home/eng/Health_standards/ta $\underline{\mathrm{hm} / 3.04 .07 \mathrm{BVD} . \mathrm{pdf}}$

OKUMU T. A., NJENGA, M. J., JAMES K., W., VICTOR T. AND JOHN V. 2019. Seroprevalence of antibodies for bovine viral diarrhoea virus, Brucella abortus and Neospora caninum, and their roles in the incidence of abortion/foetal loss in dairy cattle herds in Nakuru District, Kenya. BMC Veterinary Research 15:95 https://doi.org/10.1186/s12917-019-1842-8 
PAUL, H. W.; DANIEL, M. G.; ANNA, C. AND CHRISTINE, B. N. 2008. Effect of dexamethasone administration on bulls with a localized testicular infection with bovine viral diarrhea virus. The Canadian Journal of Veterinary Research 72: 56-62

ROBERT W. FULTON, A. W. CONFER, LURINDA J. BURGE, LOUIS J. PERINO, J. M. D'OFFAY, MARK E. PAYTON AND R. E. MOCK 1995. Antibody responses by cattle after vaccination with commercial viral vaccines containing bovine herpesvirus 1, bovine viral diarrhea virus, parainfluenza-3 virus, and bovine respiratory syncytial virus immunogens and subsequent revaccination at day 140. Vaccine, 13(8): 725-733.

SASHA, R. L.; FRASER, I. H.; MICHAEL, P.R. AND JOE, B. 2014. Bovine viral diarrhea: Pathogenesis and diagnosis. The Veterinary Journal 199; 201-209.

SCOTT M.D., MELISSA K. AND CHENGAPPA M.M. 2013. Pestiviruses, Veterinary Microbiology Book. Third Edition, p. 419.

SHARIFZADEH, A. ABBAS, D. AND PAYAM, G. D., 2011. Reverse transcriptase $P C R$ assay for detection of bovine viral diarrhea virus(BVDV) infection in Iranian bull' semen samples. Middle-East Journal of Scientific Research 9 (1): 132-139.

SOLTAN MOHAMED A, WILKES REBECCA P, ELSHEERY MOHAMED N, ELHAIG MAHMOUD M, RILEY MATTHEW C, AND KENNEDY MELISSA A. 2015. Circulation of bovine viral diarrhea virus - 1 (BVDV-1) in dairy cattle and buffalo farms in Ismailia Province, Egypt. J Infect Dev Ctries; 9(12):1331-1337.

SPETTER MJ, URIARTE EL, ALTAMIRANDA EA, LEUNDA MR, PEREYRA SB, VERNA AE AND ODEÓN AC. 2018. Dual natural infection with bovine viral diarrhea virus -1 and -2 in a stillborn calf: tissue distribution and molecular characterization. Open Vet J. 8(4):493-497.

STACEY R. BYERS, JAMES F. EVERMANN, DANIEL S. BRADWAY, AMANDA L. GRIMM, JULIA F. RIDPATH, STEVEN M. PARISH, AHMED TIBARY, GEORGE M. BARRINGTON, 2011. The effects of exposure of susceptible alpacas to alpacas persistently infected with bovine viral diarrhea virus. Can Vet J; 52:263-271

STÅHL K AND ALENIUS S: 2012, BVDV control and eradication in Europe - an update. Jpn $\mathrm{J}$ Vet Res. 60:S31-9.

TRAMUTA, C.; DANIELA, L.; SIMONA, Z.; MARIELLA, G.; ALESSANDRO, D.; EZIO F.; PATRIZIA, N. AND SERGIO, R. 2011. Development of a set of multiplex standard polymerase chain reaction assays for the identification of infectious agents from aborted bovine clinical samples. Journal of Veterinary Diagnostic Investigation 23(4) 657-664.

VALDINETE A. N., JOÃO H., ABDALla S. D., CRISTINA S. M., KARINA P. P., ANTONIO J. L., ET AL. 2020. Oropouche virus detection in saliva and urine. Mem Inst Oswaldo Cruz, Rio de Janeiro, Vol. $115,1-5$

VOLKER M. AND PAUL B. 2018. Control of Bovine Viral Diarrhea. Pathogens.; 7(1): 29.
WANG, W.; XINCHUAN, S.; OIN, T.; YONGWANG, W.; MING, Q.X.; YE, J. ET AL., 2014. A bovine viral diarrhea virus type 1a strain in China: Isolation, identification and experimental infection in calves. Virology Journal 11; 8 1-8

How to cite this article:

Marwa F. Mahmoud, Hassan H.M. and Jehan A. Gafer. 2020. Possibility of Using Urine Samples for Detection of Bovine Viral Diarrhea Virus in Egyptian Cattle. Journal of Applied Veterinary Sciences, 5(3): 71 - 77.

DOI: HTTPS://DX.DOI.ORG/10.21608/JAVS.2020.100145 